Article

\title{
Declining Energy Intensity in the U.S. Agricultural Sector: Implications for Factor Substitution and Technological Change
}

\section{Dong Hee Suh}

Food and Resource Economics Department, University of Florida, Gainesville, FL 32611-0240, USA; E-Mail:do1ghsuh@ufl.edu Academic Editor: Marc A. Rosen

Received: 7 August 2015 / Accepted: 23 September 2015 / Published: 25 September 2015

\begin{abstract}
This study examines factor substitution and energy intensity in the U.S. agricultural sector. Not only does this study focus on the substitution possibilities between energy and non-energy factors, but it also attempts to identify the factors that determine energy intensity. For the empirical analysis, a system of share equations for capital, energy and labor is estimated to calculate the price elasticities of factor demand. The findings reveal that energy demand is more elastic than the demand for capital and labor, and factor substitution possibilities exist across farm production regions. Moreover, the growth rate of energy intensity is decomposed into various driving forces, such as changes in budget, factor substitution, output and technology. The findings show that the budget and output effects are the major driving forces behind the reduced energy intensity, while there are few factor substitutions and technological improvements to reduce energy intensity in the U.S. agricultural sector.
\end{abstract}

Keywords: energy intensity; agriculture; factor substitution; technology

\section{Introduction}

In the United States, farm production has increased due to the growth of productivity over the last few decades. According to the Economic Research Service of the United States Department of Agriculture (USDA-ERS), the annual growth rate of the total factor productivity (TFP) was more than $1.4 \%$ between 1948 and 2011, which contributed to substantial increases in agricultural outputs (Figure 1). On average, agricultural outputs increased at an annual rate of $1.5 \%$, and the use of production factors grew at an annual rate of less than $0.1 \%$ [1]. The growth of production factors has been remarkably stable, but 
the composition of production factors has changed over the period. Between 1948 and 2011, the U.S. agricultural sector decreased the amount of labor by $78 \%$ and land by $26 \%$, but it increased the amount of capital and intermediate factors (e.g., energy, chemicals, purchased services, seed and feedstock) by $140 \%$ and $65 \%$, respectively [1]. That is, the contribution of capital and intermediate factors to the agricultural output growth has been offset by the negative impact of labor and land on the growth.

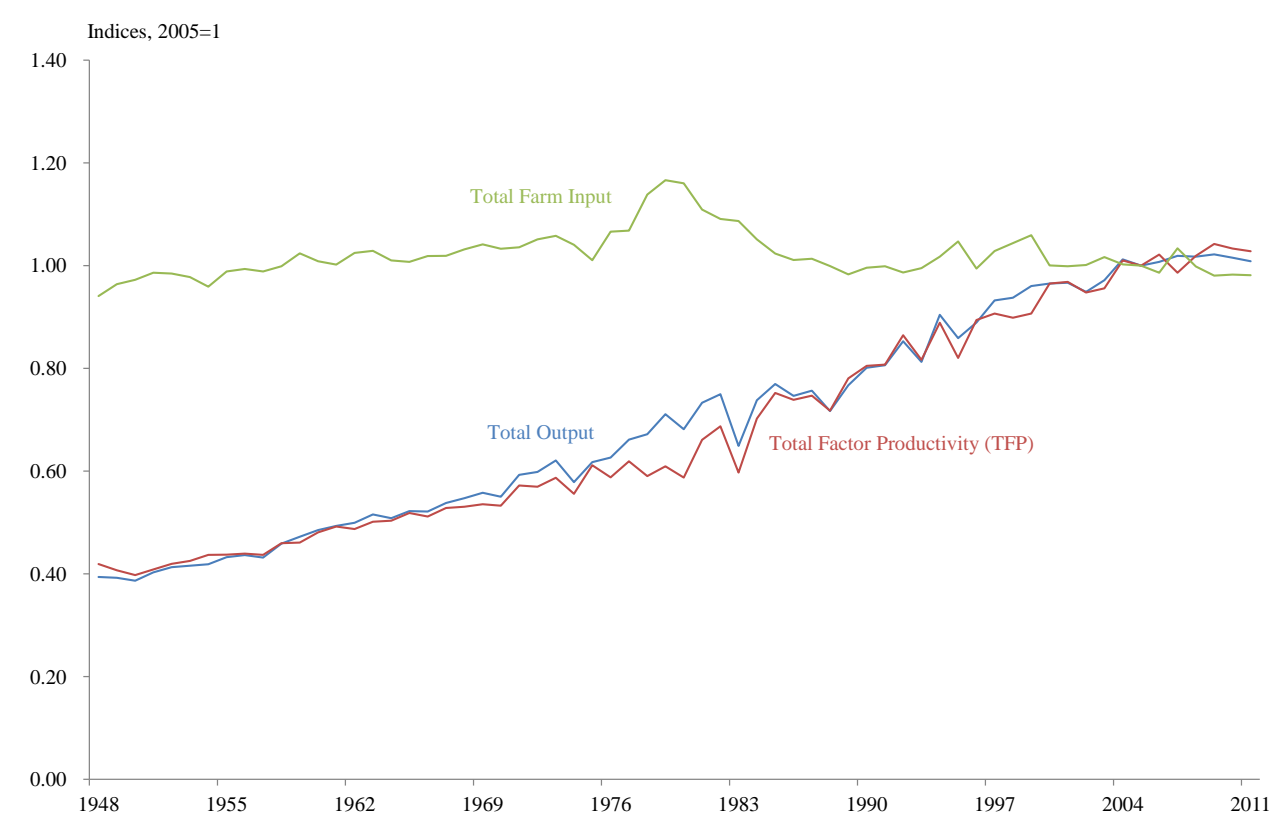

Figure 1. U.S. agricultural output, input and total factor productivity, 1948 to 2011.

While the composition of production factors has shifted from labor and land to capital and intermediate factors, energy is of great interest among intermediate factors because agricultural production is very sensitive to changes in energy prices [2-4]. (The use of energy in agricultural production is typically categorized into two types. The first is direct energy use through the combustion of diesel, electricity, propane, natural gas and renewable fuels, and the second is indirect energy use through the application of energy-intensive factors, such as fertilizers and pesticides [2-4]. Through the direct and indirect use of energy, the U.S. agricultural sector currently uses about 800 trillion British thermal units of energy according to the U.S. Energy Information Administration (EIA)). In particular, it is an interesting feature that energy intensity (i.e., the ratio of energy to output) has dramatically decreased in the U.S. agricultural sector, while energy prices have increased (Figure 2). The reduced energy intensity might be attributable to substantial increases in energy prices, advances in energy efficiency or changes in output composition [5,6]. While the increased energy prices could have forced agricultural producers to reduce the use of energy directly, factor substitution or technological improvement could have reduced energy intensity by improving energy efficiency [7-10]. If changes in the energy market conditions (e.g., energy prices) affected production costs, the U.S. agricultural sector might have increased capital investment in energy-saving technologies to counter high and volatile energy prices; or changes in output composition could have contributed to the reduction in energy intensity, because crop and livestock production systems require different energy use. 


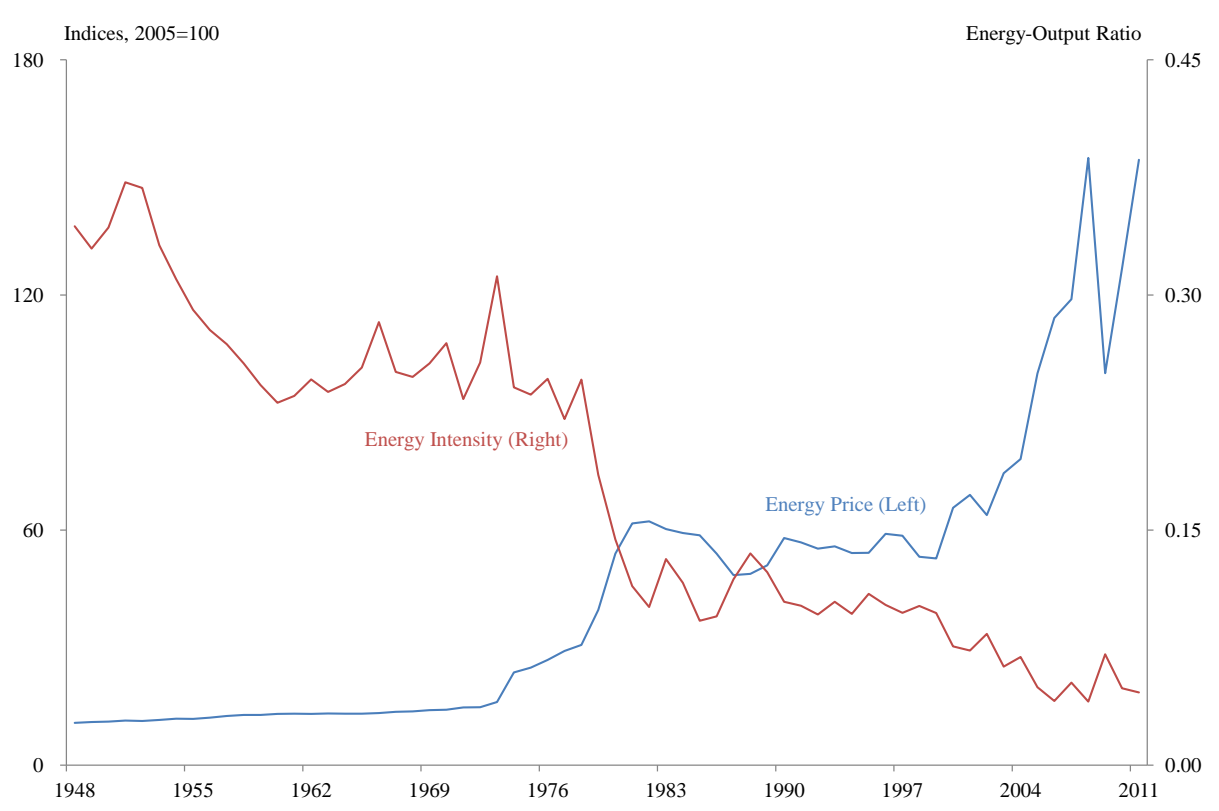

Figure 2. Energy intensity in the U.S. agricultural sector, 1948 to 2011.

However, in the literature, there has been little attention paid to the reasons for the reduced intensity of energy use in the U.S. agricultural sector. Given that energy is a critical factor for sustainable agricultural production, it is crucial to investigate empirically whether innovative activities for energy efficiency have occurred to reduce energy intensity in the U.S. agricultural sector. Thus, the objective of this study is two-fold. First, this study aims to explore the factor demand system of the U.S. agricultural sector. As many forecasts for substitution-augmenting technological improvement are based on empirically-estimated elasticities [11,12], it focuses on the price elasticities of factor demand to examine substitution possibilities between energy and non-energy factors. Second, this study attempts to identify the factors that determine energy intensity in the U.S. agricultural sector. It decomposes the growth rate of energy intensity into various driving forces, such as changes in budget, factor substitution, output and technology. In this study, factor substitution and energy intensity across farm production regions are compared to provide implications for increasingly scarce energy resources in the U.S. agricultural sector.

\section{Methods}

\subsection{Translog Cost Model}

The translog cost model is widely used to examine factor substitution possibilities [12-23]. The translog cost model in this study is constructed by a certain assumption about the production structure in the agricultural sector based on the approach of Fuss [24]. That is, the major production factors, such as capital $(K)$, energy $(E)$ and labor $(L)$, are assumed to be weakly separable from materials. Since the weak separability allows one to derive the conditional demand function for the three production factors without explicit consideration of other production factors, a non-homothetic translog factor cost function is written as: 


$$
\begin{aligned}
\ln C_{t} & =\beta_{0}+\sum_{i=1}^{n} \beta_{i} \ln P_{i t}+\frac{1}{2} \sum_{i=1}^{n} \sum_{j=1}^{n} \beta_{i j} \ln P_{i t} \cdot \ln P_{j t}+\beta_{Y} \ln Y_{t}+\frac{1}{2} \beta_{Y Y}\left(\ln Y_{t}\right)^{2} \\
& +\beta_{T} T_{t}+\frac{1}{2} \beta_{T T} T_{t}^{2}+\sum_{i=1}^{n} \beta_{i Y} \ln P_{i t} \cdot \ln Y_{t}+\sum_{i=1}^{n} \beta_{i T} \ln P_{i t} \cdot T_{t}+\beta_{Y T} \ln Y_{t} \cdot T_{t}
\end{aligned}
$$

where $C_{t}$ is total cost; $P_{i t}$ is the price of factor $i$ for $i=K, E, L ; Y_{t}$ is the level of output; $T_{t}$ denotes a time trend to capture the state of technology. In addition, $\beta$ 's are unknown parameters. The conditional factor demand functions are derived by applying Shephard's lemma. Differentiating the cost function specified in Equation (1) with respect to factor prices yields:

$$
S_{i t}=\beta_{i}+\sum_{j=1}^{n} \beta_{i j} \ln P_{j t}+\beta_{i Y} \ln Y_{t}+\beta_{i T} T_{t}
$$

where $S_{i t}$ denotes the cost share of factor $i$ for $i=K, E, L$. In Equation (2), $\beta_{i}$ and $\beta_{i j}$ represent distribution and substitution parameters, respectively [25]. The distribution and substitution parameters obey the regularity conditions, so that the cost function satisfies the restrictions corresponding to a well-behaved production function. Since the shares must add to one, an adding-up condition, $\sum_{i} \beta_{i}=1$, is imposed on the distribution parameters. For the substitution parameters, linear homogeneity in factor prices obeys $\sum_{j} \beta_{i j}=0$ for $i, j=K, E, L$, and symmetry in factor prices satisfies $\beta_{i j}=\beta_{j i}$ for all $i \neq j$. In addition, $\beta_{i Y}$ and $\beta_{i T}$ measure the effects of output composition and biased technological changes, respectively, that require adding-up restrictions, such as $\sum_{i} \beta_{i Y}=0$ and $\sum_{i} \beta_{i T}=0$.

From the estimated parameters, the price elasticities of factor demand are obtained to examine substitution possibilities between any two factors. The elasticity of the demand for factor $i$ with respect to the price of factor $j$ is calculated by:

$$
\begin{aligned}
& \eta_{i i}=\frac{\beta_{i i}}{\bar{S}_{i}}+\bar{S}_{i}-1 \\
& \eta_{i j}=\frac{\beta_{i j}}{\bar{S}_{j}} \quad \text { for } i \neq j
\end{aligned}
$$

where $\bar{S}_{i}$ is the average cost share of factor $i$ for $i=K, E, L$. The cross-price elasticities measure substitutability or complementarity. A positive $\eta_{i j}$ indicates that factors $i$ and $j$ are substitutes, while a negative $\eta_{i j}$ represents that they are complements.

\subsection{Decomposition of Energy Intensity}

Based on the approach of Welsch and Ochsen [5], energy intensity is decomposed into various influences, such as budget, factor substitution, output and technological effects. The decomposition 
of energy intensity is commonly used to examine the determinants of energy intensity [26-30]. Energy intensity at time $t\left(e_{t}\right)$ is written as:

$$
e_{t}=\frac{E_{t}}{Y_{t}}=\frac{P_{Y t}}{P_{E t}} S_{E t}
$$

where $P_{Y t}$ is the output price, $P_{E t}$ is the energy price and $S_{E t}$ is the energy cost share at time $t$. From the estimated energy share $\left(\hat{S}_{E t}\right)$, the estimated energy intensity $\left(\hat{e}_{t}\right)$ is decomposed as:

$$
\begin{aligned}
\hat{e}_{t}= & \left(\frac{P_{Y t}}{P_{E t}} \hat{\beta}_{E}\right)+\left(\frac{P_{Y t}}{P_{E t}} \hat{\beta}_{E K} \ln P_{K t}\right)+\left(\frac{P_{Y t}}{P_{E t}} \hat{\beta}_{E E} \ln P_{E t}\right)+\left(\frac{P_{Y t}}{P_{E t}} \hat{\beta}_{E L} \ln P_{L t}\right) \\
& +\left(\frac{P_{Y t}}{P_{E t}} \hat{\beta}_{E Y} \ln Y_{t}\right)+\left(\frac{P_{Y t}}{P_{E t}} \hat{\beta}_{E T} T_{t}\right)
\end{aligned}
$$

where the decomposition of energy intensity includes six terms; each term in parenthesis is represented by $\hat{e}_{B t}, \hat{e}_{K t}, \hat{e}_{E t}, \hat{e}_{L t}, \hat{e}_{Y t}$ and $\hat{e}_{T t}$, respectively. The first term $\left(\hat{e}_{B t}\right)$ measures the extent to which energy prices affect energy intensity at a given energy cost share, which represents the budget effect on energy intensity. The second through fourth terms $\left(\hat{e}_{B t}, \hat{e}_{K t}\right.$ and $\left.\hat{e}_{E t}\right)$ capture the factor substitution effects on energy intensity. In addition, the fifth term $\left(\hat{e}_{Y t}\right)$ measures the output effect on energy intensity, while the sixth term $\left(\hat{e}_{T t}\right)$ indicates the effect of technological change on energy intensity.

Based on the decomposition specified in Equation (5), the growth rate of energy intensity is measured by changes in budget, factor substitution, output and technological effects. The growth rate of energy intensity is written as:

$$
\begin{aligned}
\frac{\Delta \hat{e}_{t}}{\hat{e}_{t}}= & \left(\frac{\Delta \hat{e}_{B t}}{\hat{e}_{B t}} \frac{\hat{e}_{B t}}{\hat{e}_{t}}\right)+\left(\frac{\Delta \hat{e}_{K t}}{\hat{e}_{K t}} \frac{\hat{e}_{K t}}{\hat{e}_{t}}\right)+\left(\frac{\Delta \hat{e}_{E t}}{\hat{e}_{E t}} \frac{\hat{e}_{E t}}{\hat{e}_{t}}\right)+\left(\frac{\Delta \hat{e}_{L t}}{\hat{e}_{L t}} \frac{\hat{e}_{L t}}{\hat{e}_{t}}\right) \\
& +\left(\frac{\Delta \hat{e}_{Y t}}{\hat{e}_{Y t}} \frac{\hat{e}_{Y t}}{\hat{e}_{t}}\right)+\left(\frac{\Delta \hat{e}_{T t}}{\hat{e}_{T t}} \frac{\hat{e}_{T t}}{\hat{e}_{t}}\right)
\end{aligned}
$$

where $\Delta \hat{e}_{t} / \hat{e}_{t}$ is the growth rate of aggregate energy intensity and $\Delta \hat{e}_{i t} / \hat{e}_{i t}$ denotes the growth rate of each attribute for $i=B, K, E, L, Y, T$. In addition, $\hat{e}_{i t}$ and $\hat{e}_{t}$ indicate energy intensity in a baseline year. The decomposition in Equation (6) indicates the long-term changes in energy intensity. The positive sign of the term on the right side of Equation (6) indicates that the attribute contributes to an increase in energy intensity, but the negative sign represents that the attribute contributes to a decrease in energy intensity.

\section{Empirical Results}

\subsection{Data and Estimation Results}

Data are obtained from the Agricultural Productivity published by the USDA-ERS [31]. The data contain the indices of relative prices and implicit quantities of capital, energy and labor, as well as output across 48 states for the period from 1960 to 2004: a panel dataset with a total of 2160 observation. 
The data for the 48 states are grouped into 10 production regions according to geographic location of production, which allows reflecting similarities in agricultural production (Table 1). The production regions are classified into the Northeast, Lake States, Corn Belt, Northern Plains, Appalachian, Southeast, Delta States, Southern Plains, Mountain and Pacific regions [32]. It is typically considered that grains, such as corn and soybeans, are grown in the Corn Belt, Northern Plains and Southern Plains; oil production is concentrated in the Southeast and Delta States; and fruits and vegetables are grown mainly in the Southeast, Mountain and Pacific regions. Moreover, beef production is clustered into the Corn Belt and Northern Plains; dairy production is focused in the Northeast, Lake States and Corn Belt; and poultry production is concentrated in the Southeast region. Figure 3 describes regional differences in energy intensity calculated by taking the average of the states' energy intensity within each production region. While there were regional differences in energy intensity across the production regions, energy intensity significantly decreased between 1960 and 2004.

Table 1. Regional classification.

\begin{tabular}{ll}
\hline Regions & States \\
\hline Northeast & Connecticut, Delaware, Maryland, Maine, Massachusetts, New Hampshire, \\
& New Jersey, New York, Pennsylvania, Rhode Island, Vermont \\
Lake States & Michigan, Minnesota, Wisconsin \\
Corn Belt & Illinois, Indiana, Iowa, Missouri, Ohio \\
Northern Plains & Kansas, Nebraska, North Dakota, South Dakota \\
Appalachian & Kentucky, North Carolina, Tennessee, Virginia, West Virginia \\
Southeast & Florida, Georgia, Alabama, South Carolina \\
Delta States & Arkansas, Louisiana, Mississippi \\
Southern Plains & Oklahoma, Texas \\
Mountain & Arizona, Colorado, Idaho, Montana, Nevada, New Mexico, Utah, Wyoming \\
Pacific & California, Oregon, Washington \\
\hline
\end{tabular}

Source: Farm Production Regions, USDA-ERS [32].

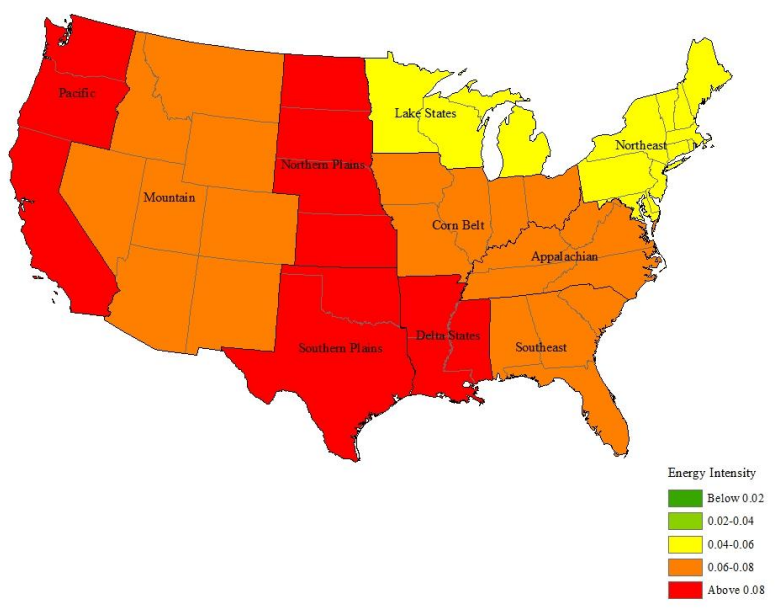

(a)

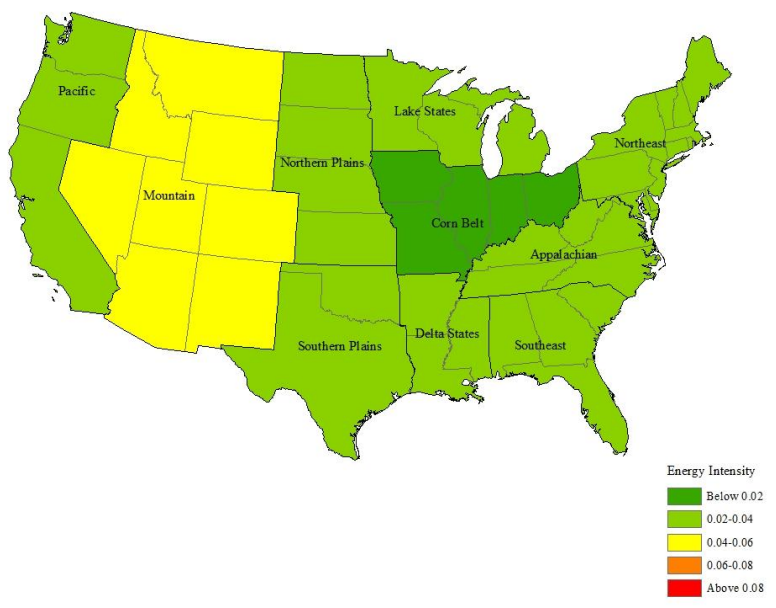

(b)

Figure 3. (a) Energy intensity in 1960; (b) energy intensity in 2004.

The factor share equations specified in Equation (2) are estimated by using the pooled time series data for a cross-section of 10 production regions. To account for regional differences, regional dummy 
variables are added to Equation (2); the variable equals 1 for a specific production region and 0 for the other production regions. In addition, a structural dummy variable is included to account for two oil crises over the sample period; the variable is equal to 1 for the 1973 to 1974 and 1979 to 1980 periods and 0 for the other periods. The iterative seemingly unrelated regression technique is used in the estimation procedure, which ignores serial correlation in the error term (autocorrelation), but accounts for error correlations across equations [17]. While both homogeneity and symmetry restrictions are imposed on factor prices, the labor share equation is dropped because the parameters for this equation are retrieved by using the adding-up restrictions. The estimation results are presented in Table 2, and the model specification is characterized by high $R$ squared.

\subsection{Factor Substitution}

The estimated parameters in Table 2 are used to calculate the price elasticities of factor demand based on Equation (3). The price elasticities of factor demand reported in Table 3 are evaluated at the five-year average factor shares for the periods of 1960 to 1964 and 2000 to 2004 to represent the estimates in the 1960s and 2000s, respectively. In the estimated price elasticities of factor demand, all own-price elasticities are negative and statistically significant, showing that the own-price elasticities of capital and energy demand in the 2000s are less than in the 1960s, but those of labor demand are greater. In the $2000 \mathrm{~s}$, for instance, a $1 \%$ increase in the own prices reduces the demand for capital, energy and labor by $0.67 \%, 0.98 \%$ and $0.34 \%$, respectively, at the national level. The differences in the extent to which factor demand responds to its own price are relatively small across the production regions. Specifically, in the 2000s, the absolute values of the own-price elasticities of capital demand range from 0.62 (Corn Belt) to 0.72 (Pacific), while those of energy demand vary from 0.94 (Mountain) to 1.03 (Appalachian). The absolute values of the own-price elasticities of labor demand range from 0.26 (Pacific) to 0.41 (Northern Plains). While labor demand is the most inelastic, energy demand is more elastic than the other factors, which represents that the U.S. agricultural sector is relatively flexible to change energy demand in response to volatile energy prices (The estimated own-price elasticities are close to the long-run estimates obtained by Griffin and Gregory [14], Pindyck [17] and Pindyck and Rotemberg [33]). Statistical evidence implies that it is easier for most agricultural producers to adjust energy demand rather than capital or labor demand. From the survey results of Beckman et al. [4], it is likely that they adjust the absolute amount of energy directly in response to changes in energy prices.

In addition, the estimated cross-price elasticities presented in Table 3 reveal significant substitution possibilities among the three factors. In the 1960s, statistical evidence shows that there are no substitutable relationships between capital and energy, except for the Northern Plains, whereas complementary relationships are shown in some production regions, such as the Northeast, Lake States, Northern Plains, Southeast and Delta States. However, capital and energy become substitutes in the 2000s (Debertin et al. [34] show that energy in agriculture is a complement for machinery in the 1950s, but it is a substitute in the 1970s). In the 2000s, statistical evidence reveals that the extent to which capital substitutes for energy (0.05) is less than that to which energy substitutes for capital (0.16) at the national level. It is more likely that the U.S. agricultural sector adjusts energy demand in response to capital prices rather than capital demand in response to energy prices. Similar substitution possibilities between 
capital and energy are also shown across the production regions in the 2000s. The substitution of capital for energy occurs with a range from 0.03 (Appalachian) to 0.08 (Northern Plains), while the substitution of energy for capital occurs with a range from 0.08 (Pacific) to 0.23 (Northern Plains). The substitution of capital for energy implies that an increase in energy prices contributes to capital intensiveness in these regions, but the extent to which capital is invested in energy-saving operations is relatively small for each region.

Table 2. Estimation results of factor share equations.

\begin{tabular}{|c|c|c|c|c|}
\hline \multirow[b]{2}{*}{ Variables } & \multicolumn{2}{|c|}{ Equation 1} & \multicolumn{2}{|c|}{ Equation 2} \\
\hline & Parameters & Estimates & Parameters & Estimates \\
\hline Capital & $\beta_{K K}$ & $\begin{array}{c}0.019 * * * \\
(0.003)\end{array}$ & $\beta_{E K}$ & $\begin{array}{c}-0.007 * * * \\
(0.002)\end{array}$ \\
\hline Energy & $\beta_{K E}$ & $\begin{array}{c}-0.008 * * * \\
(0.002)\end{array}$ & $\beta_{E E}$ & $\begin{array}{c}-0.006 * * * \\
(0.002)\end{array}$ \\
\hline Labor & $\beta_{K L}$ & $\begin{array}{c}-0.011 * * * \\
(0.003)\end{array}$ & $\beta_{E L}$ & $\begin{array}{c}0.013 * * * \\
(0.001)\end{array}$ \\
\hline Output & $\beta_{K Y}$ & $\begin{array}{c}-0.007 * * * \\
(0.001)\end{array}$ & $\beta_{E Y}$ & $\begin{array}{c}0.004 * * * \\
(0.000)\end{array}$ \\
\hline Technology & $\beta_{K T}$ & $\begin{array}{c}0.002 * * * \\
(0.000)\end{array}$ & $\beta_{E T}$ & $\begin{array}{c}0.001 * * * \\
(0.000)\end{array}$ \\
\hline Structure & $\beta_{K S}$ & $\begin{array}{c}0.029 * * * \\
(0.004)\end{array}$ & $\beta_{E S}$ & $\begin{array}{c}0.003 * * * \\
(0.001)\end{array}$ \\
\hline Northeast & $\beta_{K 1}$ & $\begin{array}{c}0.234 * * * \\
(0.012)\end{array}$ & $\beta_{E 1}$ & $\begin{array}{c}-0.008 * * * \\
(0.004)\end{array}$ \\
\hline Lake States & $\beta_{K 2}$ & $\begin{array}{c}0.281 * * * \\
(0.015)\end{array}$ & $\beta_{E 2}$ & $\begin{array}{c}-0.011 * * * \\
(0.004)\end{array}$ \\
\hline Corn Belt & $\beta_{K 3}$ & $\begin{array}{c}0.320 * * * \\
(0.015)\end{array}$ & $\beta_{E 3}$ & $\begin{array}{l}-0.006 \\
(0.004)\end{array}$ \\
\hline Northern Plains & $\beta_{K 4}$ & $\begin{array}{c}0.309 * * * \\
(0.015)\end{array}$ & $\beta_{E 4}$ & $\begin{array}{c}0.018 * * * \\
(0.004)\end{array}$ \\
\hline Appalachian & $\beta_{K 5}$ & $\begin{array}{c}0.245 * * * \\
(0.014)\end{array}$ & $\beta_{E 5}$ & $\begin{array}{c}-0.009 * * \\
(0.004)\end{array}$ \\
\hline Southeast & $\beta_{K 6}$ & $\begin{array}{c}0.231 * * * \\
(0.014)\end{array}$ & $\beta_{E 6}$ & $\begin{array}{l}0.007 * \\
(0.004)\end{array}$ \\
\hline Delta States & $\beta_{K 7}$ & $\begin{array}{c}0.262 * * * \\
(0.014)\end{array}$ & $\beta_{E 7}$ & $\begin{array}{c}0.018 * * * \\
(0.004)\end{array}$ \\
\hline Southern Plains & $\beta_{K 8}$ & $\begin{array}{c}0.258 * * * \\
(0.015)\end{array}$ & $\beta_{E 8}$ & $\begin{array}{c}0.010 * * \\
(0.004)\end{array}$ \\
\hline Mountain & $\beta_{K 9}$ & $\begin{array}{c}0.253 * * * \\
(0.013)\end{array}$ & $\beta_{E 9}$ & $\begin{array}{c}0.025 * * * \\
(0.004)\end{array}$ \\
\hline Pacific & $\beta_{K 10}$ & $\begin{array}{c}0.217 * * * \\
(0.015)\end{array}$ & $\beta_{E 10}$ & $\begin{array}{c}0.006 \\
(0.004)\end{array}$ \\
\hline$R$-squared & $R_{K}^{2}$ & 0.965 & $R_{E}^{2}$ & 0.958 \\
\hline
\end{tabular}

Note: Standard errors are in parentheses; *** Denotes statistical significance at the $1 \%$ level; ** Denotes statistical significance at the $5 \%$ level; * Denotes statistical significance at the $10 \%$ level. 
Table 3. Price elasticities of factor demand.

\begin{tabular}{|c|c|c|c|c|c|c|c|c|c|}
\hline & $\eta_{K K}$ & $\eta_{E E}$ & $\eta_{L L}$ & $\eta_{K E}$ & $\eta_{K L}$ & $\eta_{E K}$ & $\eta_{E L}$ & $\eta_{L K}$ & $\eta_{L E}$ \\
\hline \multicolumn{10}{|l|}{$1960 \mathrm{~s}$} \\
\hline U.S. & $\begin{array}{c}-0.724 * * * \\
(0.022)\end{array}$ & $\begin{array}{c}-1.114 * * * \\
(0.041)\end{array}$ & $\begin{array}{c}-0.196 * * * \\
(0.004)\end{array}$ & $\begin{array}{l}-0.011 \\
(0.011)\end{array}$ & $\begin{array}{c}0.735 * * * \\
(0.020)\end{array}$ & $\begin{array}{l}-0.049 \\
(0.048)\end{array}$ & $\begin{array}{c}1.163 * * * \\
(0.025)\end{array}$ & $\begin{array}{c}0.143 * * * \\
(0.004)\end{array}$ & $\begin{array}{c}0.053 * * * \\
(0.001)\end{array}$ \\
\hline Northeast & $\begin{array}{c}-0.725 * * * \\
(0.023)\end{array}$ & $\begin{array}{c}-1.202 * * * \\
(0.062)\end{array}$ & $\begin{array}{c}-0.180 * * * \\
(0.004)\end{array}$ & $\begin{array}{c}-0.025 * * \\
(0.011)\end{array}$ & $\begin{array}{c}0.750 * * * \\
(0.021)\end{array}$ & $\begin{array}{c}-0.156 * * \\
(0.072)\end{array}$ & $\begin{array}{c}1.358 * * * \\
(0.037)\end{array}$ & $\begin{array}{c}0.140 * * * \\
(0.004)\end{array}$ & $\begin{array}{c}0.040 * * * \\
(0.001)\end{array}$ \\
\hline Lake States & $\begin{array}{c}-0.721 * * * \\
(0.021)\end{array}$ & $\begin{array}{c}-1.185 * * * \\
(0.058)\end{array}$ & $\begin{array}{c}-0.197 * * * \\
(0.004)\end{array}$ & $\begin{array}{c}-0.019 * \\
(0.011)\end{array}$ & $\begin{array}{c}0.740 * * * \\
(0.019)\end{array}$ & $\begin{array}{c}-0.121 * \\
(0.068)\end{array}$ & $\begin{array}{c}1.307 * * * \\
(0.035)\end{array}$ & $\begin{array}{c}0.154 * * * \\
(0.004)\end{array}$ & $\begin{array}{c}0.042 * * * \\
(0.001)\end{array}$ \\
\hline Corn Belt & $\begin{array}{c}-0.717 * * * \\
(0.020)\end{array}$ & $\begin{array}{c}-1.127 * * * \\
(0.044)\end{array}$ & $\begin{array}{c}-0.214 * * * \\
(0.005)\end{array}$ & $\begin{array}{l}-0.008 \\
(0.010)\end{array}$ & $\begin{array}{c}0.726 * * * \\
(0.018)\end{array}$ & $\begin{array}{l}-0.043 \\
(0.051)\end{array}$ & $\begin{array}{c}1.170 * * * \\
(0.027)\end{array}$ & $\begin{array}{c}0.163 * * * \\
(0.004)\end{array}$ & $\begin{array}{c}0.051 \text { *** } \\
(0.001)\end{array}$ \\
\hline Northern Plains & $\begin{array}{c}-0.696 * * * \\
(0.016)\end{array}$ & $\begin{array}{c}-1.051 * * * \\
(0.028)\end{array}$ & $\begin{array}{c}-0.274 * * * \\
(0.005)\end{array}$ & $\begin{array}{c}0.019 * * \\
(0.008)\end{array}$ & $\begin{array}{c}0.678 * * * \\
(0.015)\end{array}$ & $\begin{array}{c}0.076 * * \\
(0.033)\end{array}$ & $\begin{array}{c}0.975 * * * \\
(0.017)\end{array}$ & $\begin{array}{c}0.203 * * * \\
(0.004)\end{array}$ & $\begin{array}{c}0.071 * * * \\
(0.001)\end{array}$ \\
\hline Appalachian & $\begin{array}{c}-0.724 * * * \\
(0.029)\end{array}$ & $\begin{array}{c}-1.218 * * * \\
(0.066)\end{array}$ & $\begin{array}{c}-0.144 * * * \\
(0.004)\end{array}$ & $\begin{array}{c}-0.041 * * * \\
(0.015)\end{array}$ & $\begin{array}{c}0.765 * * * \\
(0.027)\end{array}$ & $\begin{array}{c}-0.210 * * * \\
(0.077)\end{array}$ & $\begin{array}{c}1.428 * * * \\
(0.040)\end{array}$ & $\begin{array}{c}0.106 * * * \\
(0.004)\end{array}$ & $\begin{array}{c}0.038 * * * \\
(0.001)\end{array}$ \\
\hline Southeast & $\begin{array}{c}-0.722 * * * \\
(0.030)\end{array}$ & $\begin{array}{c}-1.116 * * * \\
(0.042)\end{array}$ & $\begin{array}{c}-0.153 * * * \\
(0.004)\end{array}$ & $\begin{array}{c}-0.030 * \\
(0.016)\end{array}$ & $\begin{array}{c}0.752 * * * \\
(0.028)\end{array}$ & $\begin{array}{c}-0.094 * \\
(0.049)\end{array}$ & $\begin{array}{c}1.210 * * * \\
(0.025)\end{array}$ & $\begin{array}{c}0.101 * * * \\
(0.004)\end{array}$ & $\begin{array}{c}0.052 * * * \\
(0.001)\end{array}$ \\
\hline Delta States & $\begin{array}{c}-0.713 * * * \\
(0.035)\end{array}$ & $\begin{array}{c}-1.112 * * * \\
(0.041)\end{array}$ & $\begin{array}{c}-0.140 * * * \\
(0.004)\end{array}$ & $\begin{array}{c}-0.038 * * * \\
(0.018)\end{array}$ & $\begin{array}{c}0.752 * * * \\
(0.032)\end{array}$ & $\begin{array}{c}-0.104 * * \\
(0.048)\end{array}$ & $\begin{array}{c}1.216 * * * \\
(0.025)\end{array}$ & $\begin{array}{c}0.088 * * * \\
(0.004)\end{array}$ & $\begin{array}{c}0.052 * * * \\
(0.001)\end{array}$ \\
\hline Southern Plains & $\begin{array}{c}-0.724 * * * \\
(0.022)\end{array}$ & $\begin{array}{c}-1.071 * * * \\
(0.032)\end{array}$ & $\begin{array}{c}-0.206 * * * \\
(0.005)\end{array}$ & $\begin{array}{l}-0.002 \\
(0.011)\end{array}$ & $\begin{array}{c}0.726 * * * \\
(0.020)\end{array}$ & $\begin{array}{l}-0.005 \\
(0.038)\end{array}$ & $\begin{array}{c}1.076 * * * \\
(0.019)\end{array}$ & $\begin{array}{c}0.142 * * * \\
(0.004)\end{array}$ & $\begin{array}{c}0.063 \text { *** } \\
(0.001)\end{array}$ \\
\hline Mountain & $\begin{array}{c}-0.715 * * * \\
(0.019)\end{array}$ & $\begin{array}{c}-1.048 * * * \\
(0.028)\end{array}$ & $\begin{array}{c}-0.240 * * * \\
(0.005)\end{array}$ & $\begin{array}{c}0.013 \\
(0.010)\end{array}$ & $\begin{array}{c}0.702 * * * \\
(0.017)\end{array}$ & $\begin{array}{c}0.043 \\
(0.033)\end{array}$ & $\begin{array}{c}1.005 * * * \\
(0.017)\end{array}$ & $\begin{array}{c}0.168 * * * \\
(0.004)\end{array}$ & $\begin{array}{c}0.071 * * * \\
(0.001)\end{array}$ \\
\hline Pacific & $\begin{array}{c}-0.724 * * * \\
(0.022)\end{array}$ & $\begin{array}{c}-1.085 * * * \\
(0.035)\end{array}$ & $\begin{array}{c}-0.203 * * * \\
(0.005)\end{array}$ & $\begin{array}{l}-0.005 \\
(0.011)\end{array}$ & $\begin{array}{c}0.729 * * * \\
(0.020)\end{array}$ & $\begin{array}{l}-0.019 \\
(0.041)\end{array}$ & $\begin{array}{c}1.104 * * * \\
(0.021)\end{array}$ & $\begin{array}{c}0.143 * * * \\
(0.004)\end{array}$ & $\begin{array}{c}0.060 * * * \\
(0.001)\end{array}$ \\
\hline \multicolumn{10}{|l|}{$2000 \mathrm{~s}$} \\
\hline U.S. & $\begin{array}{c}-0.672 * * * \\
(0.014)\end{array}$ & $\begin{array}{c}-0.983 * * * \\
(0.018)\end{array}$ & $\begin{array}{c}-0.341 * * * \\
(0.005)\end{array}$ & $\begin{array}{c}0.053 * * * \\
(0.007)\end{array}$ & $\begin{array}{c}0.618 * * * \\
(0.013)\end{array}$ & $\begin{array}{c}0.164 * * * \\
(0.021)\end{array}$ & $\begin{array}{c}0.820 * * * \\
(0.011)\end{array}$ & $\begin{array}{c}0.238 * * * \\
(0.005)\end{array}$ & $\begin{array}{c}0.103 * * * \\
(0.001)\end{array}$ \\
\hline Northeast & $\begin{array}{c}-0.691 * * * \\
(0.015)\end{array}$ & $\begin{array}{c}-1.014 * * * \\
(0.022)\end{array}$ & $\begin{array}{c}-0.297 * * * \\
(0.005)\end{array}$ & $\begin{array}{c}0.034 * * * \\
(0.008)\end{array}$ & $\begin{array}{c}0.656 * * * \\
(0.014)\end{array}$ & $\begin{array}{c}0.115 * * * \\
(0.026)\end{array}$ & $\begin{array}{c}0.899 * * * \\
(0.013)\end{array}$ & $\begin{array}{c}0.211 * * * \\
(0.005)\end{array}$ & $\begin{array}{c}0.087 \text { *** } \\
(0.001)\end{array}$ \\
\hline Lake States & $\begin{array}{c}-0.628 * * * \\
(0.011)\end{array}$ & $\begin{array}{c}-0.992 * * * \\
(0.019)\end{array}$ & $\begin{array}{c}-0.394 * * * \\
(0.006)\end{array}$ & $\begin{array}{c}0.054 * * * \\
(0.006)\end{array}$ & $\begin{array}{c}0.573 * * * \\
(0.010)\end{array}$ & $\begin{array}{c}0.216 * * * \\
(0.023)\end{array}$ & $\begin{array}{c}0.776 * * * \\
(0.012)\end{array}$ & $\begin{array}{c}0.294 * * * \\
(0.005)\end{array}$ & $\begin{array}{c}0.100 * * * \\
(0.002)\end{array}$ \\
\hline Corn Belt & $\begin{array}{c}-0.620 * * * \\
(0.011)\end{array}$ & $\begin{array}{c}-1.007 * * * \\
(0.021)\end{array}$ & $\begin{array}{c}-0.397 * * * \\
(0.006)\end{array}$ & $\begin{array}{c}0.048 * * * \\
(0.006)\end{array}$ & $\begin{array}{c}0.572 * * * \\
(0.010)\end{array}$ & $\begin{array}{c}0.215 * * * \\
(0.025)\end{array}$ & $\begin{array}{c}0.791 * * * \\
(0.013)\end{array}$ & $\begin{array}{c}0.304 * * * \\
(0.005)\end{array}$ & $\begin{array}{c}0.093 * * * \\
(0.002)\end{array}$ \\
\hline Northern Plains & $\begin{array}{c}-0.640 * * * \\
(0.012)\end{array}$ & $\begin{array}{c}-0.944 * * * \\
(0.014)\end{array}$ & $\begin{array}{c}-0.408 * * * \\
(0.006)\end{array}$ & $\begin{array}{c}0.082 * * * \\
(0.006)\end{array}$ & $\begin{array}{c}0.558 * * * \\
(0.011)\end{array}$ & $\begin{array}{c}0.226 * * * \\
(0.016)\end{array}$ & $\begin{array}{c}0.717 * * * \\
(0.008)\end{array}$ & $\begin{array}{c}0.278 * * * \\
(0.005)\end{array}$ & $\begin{array}{c}0.130 * * * \\
(0.002)\end{array}$ \\
\hline Appalachian & $\begin{array}{c}-0.671 * * * \\
(0.014)\end{array}$ & $\begin{array}{c}-1.025 * * * \\
(0.024)\end{array}$ & $\begin{array}{c}-0.322 * * * \\
(0.005)\end{array}$ & $\begin{array}{c}0.033 * * * \\
(0.007)\end{array}$ & $\begin{array}{c}0.637 * * * \\
(0.012)\end{array}$ & $\begin{array}{c}0.136 * * * \\
(0.028)\end{array}$ & $\begin{array}{c}0.889 * * * \\
(0.015)\end{array}$ & $\begin{array}{c}0.240 * * * \\
(0.005)\end{array}$ & $\begin{array}{c}0.082 * * * \\
(0.001)\end{array}$ \\
\hline Southeast & $\begin{array}{c}-0.684 * * * \\
(0.015)\end{array}$ & $\begin{array}{c}-0.981 * * * \\
(0.018)\end{array}$ & $\begin{array}{c}-0.324 * * * \\
(0.005)\end{array}$ & $\begin{array}{c}0.053 * * * \\
(0.007)\end{array}$ & $\begin{array}{c}0.632 * * * \\
(0.014)\end{array}$ & $\begin{array}{c}0.147 * * * \\
(0.021)\end{array}$ & $\begin{array}{c}0.833 * * * \\
(0.011)\end{array}$ & $\begin{array}{c}0.220 * * * \\
(0.005)\end{array}$ & $\begin{array}{c}0.104 * * * \\
(0.001)\end{array}$ \\
\hline Delta States & $\begin{array}{c}-0.655 * * * \\
(0.012)\end{array}$ & $\begin{array}{c}-0.946 * * * \\
(0.014)\end{array}$ & $\begin{array}{c}-0.387 * * * \\
(0.006)\end{array}$ & $\begin{array}{c}0.079 * * * \\
(0.006)\end{array}$ & $\begin{array}{c}0.576 * * * \\
(0.012)\end{array}$ & $\begin{array}{c}0.206 * * * \\
(0.017)\end{array}$ & $\begin{array}{c}0.740 * * * \\
(0.009)\end{array}$ & $\begin{array}{c}0.260 * * * \\
(0.005)\end{array}$ & $\begin{array}{c}0.127 * * * \\
(0.001)\end{array}$ \\
\hline Southern Plains & $\begin{array}{c}-0.691 * * * \\
(0.015)\end{array}$ & $\begin{array}{c}-1.001 * * * \\
(0.020)\end{array}$ & $\begin{array}{c}-0.303 * * * \\
(0.005)\end{array}$ & $\begin{array}{c}0.040 * * * \\
(0.008)\end{array}$ & $\begin{array}{c}0.651 * * * \\
(0.014)\end{array}$ & $\begin{array}{c}0.124 * * * \\
(0.024)\end{array}$ & $\begin{array}{c}0.877 * * * \\
(0.012)\end{array}$ & $\begin{array}{c}0.210 * * * \\
(0.005)\end{array}$ & $\begin{array}{c}0.093 * * * \\
(0.001)\end{array}$ \\
\hline Mountain & $\begin{array}{c}-0.679 * * * \\
(0.014)\end{array}$ & $\begin{array}{c}-0.943 * * * \\
(0.014)\end{array}$ & $\begin{array}{c}-0.356 * * * \\
(0.006)\end{array}$ & $\begin{array}{c}0.077 * * * \\
(0.007)\end{array}$ & $\begin{array}{c}0.602 * * * \\
(0.013)\end{array}$ & $\begin{array}{c}0.175 * * * \\
(0.016)\end{array}$ & $\begin{array}{c}0.768 * * * \\
(0.008)\end{array}$ & $\begin{array}{c}0.228 * * * \\
(0.005)\end{array}$ & $\begin{array}{c}0.128 * * * \\
(0.001)\end{array}$ \\
\hline Pacific & $\begin{array}{c}-0.717 * * * \\
(0.020)\end{array}$ & $\begin{array}{c}-0.991 * * * \\
(0.019)\end{array}$ & $\begin{array}{c}-0.258 * * * \\
(0.005)\end{array}$ & $\begin{array}{c}0.036 * * * \\
(0.010)\end{array}$ & $\begin{array}{c}0.681 * * * \\
(0.018)\end{array}$ & $\begin{array}{c}0.081 * * * \\
(0.022)\end{array}$ & $\begin{array}{c}0.911 * * * \\
(0.012)\end{array}$ & $\begin{array}{c}0.162 * * * \\
(0.004)\end{array}$ & $\begin{array}{c}0.096 \text { *** } \\
(0.001)\end{array}$ \\
\hline
\end{tabular}

Note: Standard errors are in parentheses; *** Denotes statistical significance at the $1 \%$ level; ** Denotes statistical significance at the 5\% level; * Denotes statistical significance at the $10 \%$ level.

Moreover, there exist substitutable relationships between labor and energy in the 1960s and 2000s. While the extent to which labor substitutes for energy in the 2000s is greater than in the 1960s, the extent to which energy substitutes for labor is less. Specifically, in the 2000s, the energy-price elasticity of labor demand is about 0.10 , but the labor-price elasticity of energy demand is about 0.82 at the national level, showing that the U.S. agricultural sector tends to increase energy use in response to an increase in labor prices. The estimates for all regions also show consistent results regarding substitutable relationships between labor and energy. While the energy-price elasticities of labor demand range from 0.08 (Appalachian) to 0.13 (Northern Plains), the labor-price elasticities of energy demand vary from 0.72 (Northern Plains) to 0.91 (Pacific). Interestingly, the U.S. agricultural sector is more likely to respond to capital and labor prices, thereby substituting energy for them. This demonstrates that there 
are more incentives for the U.S. agricultural sector to increase energy intensiveness to cope with an increase in capital and labor prices. Admittedly, the U.S. agricultural sector also increases labor and capital intensiveness in response to an increase in energy prices, but the extent to which it replaces energy with capital and labor is very small for each region.

\subsection{Energy Intensity}

The decomposition method allows one to identify the driving forces of energy intensity changes in the U.S. agricultural sector. While energy intensity is decomposed into budget, substitution, output and technological effects, the decomposition of the growth rate of energy intensity shows how much the driving forces have contributed to changes in energy intensity over the period from 1960 to 2004. Again, the five-year average values for the periods of 1960 to 1964 and 2000 to 2004 are used for the base and comparison year, respectively. Table 4 reveals the decomposition results of energy intensity changes based on Equation (6). The estimated energy intensity at the national level decreased by about $37.8 \%$, which was driven mainly by the budget (24.5\%) and output (21.3\%) effects. While the U.S. agricultural sector experienced the substantial growth of productivity to reduce energy use, the sector should reduce energy intensity because agricultural producers could not endure increasing energy costs under their budget constraints. On the other hand, factor substitution had little influence on the reduced energy intensity. The increased capital price triggered the reduction in energy intensity by $0.3 \%$, whereas the increased wage rate increased energy intensity by $6.0 \%$. There was also little technological improvement to reduce energy intensity. The direction was from energy-intensive to energy-saving technology, but it contributed to the reduction in energy intensity only by $0.5 \%$.

The estimated energy intensity also decreased at the regional level with a range from $24.6 \%$ (Mountain) to $47.5 \%$ (Corn Belt). The budget effect was one of the main driving forces across the production regions, which varied from $15.8 \%$ (Mountain) to $32.1 \%$ (Delta States). Most production regions could not afford to bear the increased energy costs under their budget constraints. The output effect was also another driving factor that consistently contributed to the reduction in energy intensity across the production regions. From the negative output effects with a range from $13.4 \%$ (Mountain) to $25.9 \%$ (Delta States), statistical evidence reveals that the increased agricultural production has required less energy, inducing the reduced energy intensity.

On the other hand, there exist regional differences in factor substitution effects due to changes in the substitution rates between energy and non-energy factors. The energy substitution for capital had little contribution to the reduction in energy intensity. While capital prices decreased energy intensity in the Lake States $(0.9 \%)$, Appalachian $(0.4 \%)$, Southeast $(0.8 \%)$ and Mountain $(7.1 \%)$ regions, they increased energy intensity in the Northeast (0.2\%), Corn Belt (3.1\%), Northern Plains (2.5\%), Delta States (3.9\%), Southern Plains (1.2\%) and Pacific $(0.6 \%)$ regions. However, the energy substitution for labor increased energy intensity in most regions, except for the Corn Belt. While the substitution of energy for labor reduced energy intensity in the Corn Belt by $1.6 \%$, the factor substitution effects led to an increase in energy intensity with a range from $2.5 \%$ (Southern Plains) to $13.7 \%$ (Mountain). 
Table 4. Decomposition of energy intensity change.

\begin{tabular}{|c|c|c|c|c|c|c|c|}
\hline & \multirow{2}{*}{$\frac{\Delta e}{e}$} & \multirow{2}{*}{ Budget } & \multicolumn{3}{|c|}{ Substitution } & \multirow{2}{*}{ Output } & \multirow{2}{*}{ Technology } \\
\hline & & & Capital & Energy & Labor & & \\
\hline U.S. & $\begin{array}{c}-0.378 * * * \\
(0.013)\end{array}$ & $\begin{array}{c}-0.245 * * * \\
(0.092)\end{array}$ & $\begin{array}{c}-0.003 * * \\
(0.001)\end{array}$ & $\begin{array}{c}0.027 * * \\
(0.012)\end{array}$ & $\begin{array}{c}0.060 * * \\
(0.026)\end{array}$ & $\begin{array}{c}-0.213 * \\
(0.111)\end{array}$ & $\begin{array}{c}-0.005 * * \\
(0.002)\end{array}$ \\
\hline Northeast & $\begin{array}{c}-0.412 * * * \\
(0.006)\end{array}$ & $\begin{array}{c}-0.262 * * * \\
(0.094)\end{array}$ & $\begin{array}{l}0.002 * \\
(0.001)\end{array}$ & $\begin{array}{c}0.033 * * \\
(0.016)\end{array}$ & $\begin{array}{c}0.038 * * \\
(0.017)\end{array}$ & $\begin{array}{c}-0.217 * \\
(0.117)\end{array}$ & $\begin{array}{c}-0.005 * * \\
(0.002)\end{array}$ \\
\hline Lake States & $\begin{array}{c}-0.315 * * * \\
(0.032)\end{array}$ & $\begin{array}{c}-0.235 * * * \\
(0.089)\end{array}$ & $\begin{array}{c}-0.009 * * \\
(0.005)\end{array}$ & $\begin{array}{c}0.025 * * \\
(0.011)\end{array}$ & $\begin{array}{c}0.130 * * \\
(0.055)\end{array}$ & $\begin{array}{c}-0.221 * \\
(0.115)\end{array}$ & $\begin{array}{c}-0.005 * * \\
(0.002)\end{array}$ \\
\hline Corn Belt & $\begin{array}{c}-0.475 * * * \\
(0.008)\end{array}$ & $\begin{array}{c}-0.279 * * \\
(0.112)\end{array}$ & $\begin{array}{c}0.031 * * \\
(0.015)\end{array}$ & $\begin{array}{c}0.050 * * \\
(0.022)\end{array}$ & $\begin{array}{c}-0.016 * * \\
(0.006)\end{array}$ & $\begin{array}{c}-0.256 * * \\
(0.127)\end{array}$ & $\begin{array}{c}-0.006 * * \\
(0.002)\end{array}$ \\
\hline Northern Plains & $\begin{array}{c}-0.429 * * * \\
(0.020)\end{array}$ & $\begin{array}{c}-0.281 * * * \\
(0.107)\end{array}$ & $\begin{array}{c}0.025 * * \\
(0.013)\end{array}$ & $\begin{array}{c}0.044 * * \\
(0.020)\end{array}$ & $\begin{array}{c}0.028 * * \\
(0.012)\end{array}$ & $\begin{array}{c}-0.240 * \\
(0.124)\end{array}$ & $\begin{array}{c}-0.006 * * \\
(0.003)\end{array}$ \\
\hline Appalachian & $\begin{array}{c}-0.352 * * * \\
(0.020)\end{array}$ & $\begin{array}{c}-0.249 * * * \\
(0.088)\end{array}$ & $\begin{array}{c}-0.004 * \\
(0.002)\end{array}$ & $\begin{array}{c}0.024 * * \\
(0.012)\end{array}$ & $\begin{array}{c}0.097 * * \\
(0.043)\end{array}$ & $\begin{array}{c}-0.216 * \\
(0.118)\end{array}$ & $\begin{array}{c}-0.005 * * \\
(0.002)\end{array}$ \\
\hline Southeast & $\begin{array}{c}-0.352 * * * \\
(0.017)\end{array}$ & $\begin{array}{c}-0.243 * * * \\
(0.087)\end{array}$ & $\begin{array}{c}-0.008 * \\
(0.004)\end{array}$ & $\begin{array}{c}0.023 * * \\
(0.011)\end{array}$ & $\begin{array}{c}0.086 * * \\
(0.038)\end{array}$ & $\begin{array}{c}-0.206 * \\
(0.111)\end{array}$ & $\begin{array}{c}-0.005 * * \\
(0.002)\end{array}$ \\
\hline Delta States & $\begin{array}{c}-0.416 * * * \\
(0.034)\end{array}$ & $\begin{array}{c}-0.321 * * * \\
(0.106)\end{array}$ & $\begin{array}{l}0.039 * \\
(0.021)\end{array}$ & $\begin{array}{c}0.056 * * \\
(0.027)\end{array}$ & $\begin{array}{c}0.076 * * \\
(0.036)\end{array}$ & $\begin{array}{c}-0.259 * \\
(0.147)\end{array}$ & $\begin{array}{c}-0.007 * * \\
(0.003)\end{array}$ \\
\hline Southern Plains & $\begin{array}{c}-0.435 * * * \\
(0.002)\end{array}$ & $\begin{array}{c}-0.258 * * * \\
(0.099)\end{array}$ & $\begin{array}{c}0.012 * * \\
(0.006)\end{array}$ & $\begin{array}{c}0.027 * * \\
(0.012)\end{array}$ & $\begin{array}{c}0.025 * * \\
(0.010)\end{array}$ & $\begin{array}{c}-0.236 * \\
(0.122)\end{array}$ & $\begin{array}{c}-0.005 * * \\
(0.002)\end{array}$ \\
\hline Mountain & $\begin{array}{c}-0.246 * * * \\
(0.008)\end{array}$ & $\begin{array}{c}-0.158 * * * \\
(0.058)\end{array}$ & $\begin{array}{c}-0.071 * \\
(0.037)\end{array}$ & $\begin{array}{c}-0.016 * * \\
(0.007)\end{array}$ & $\begin{array}{c}0.137 * * \\
(0.059)\end{array}$ & $\begin{array}{c}-0.134 * \\
(0.071)\end{array}$ & $\begin{array}{c}-0.003 * * \\
(0.001)\end{array}$ \\
\hline Pacific & $\begin{array}{c}-0.408 * * * \\
(0.009)\end{array}$ & $\begin{array}{c}-0.247 * * \\
(0.097)\end{array}$ & $\begin{array}{c}0.006 * * \\
(0.003)\end{array}$ & $\begin{array}{c}0.026 * * \\
(0.012)\end{array}$ & $\begin{array}{c}0.035 * * \\
(0.014)\end{array}$ & $\begin{array}{c}-0.223 * * \\
(0.113)\end{array}$ & $\begin{array}{c}-0.005 * * \\
(0.002)\end{array}$ \\
\hline
\end{tabular}

Note: Standard errors are in parentheses; *** Denotes statistical significance at the $1 \%$ level; ** Denotes statistical significance at the $5 \%$ level; * Denotes statistical significance at the $10 \%$ level.

In addition, technological changes had little contribution to the reduced energy intensity across the production regions. The technological improvement reduced energy intensity with a rage from $0.3 \%$ (Mountain) to $0.7 \%$ (Delta States), but its magnitude was very small for each region. Combined with the weak energy-capital substitution effects, the effects of technological changes on energy intensity provide critical implications for energy use in the U.S. agricultural sector. That is, the factor substitution and technological effects differ across the regions, but the extent to which their effects reduce energy intensity is not apparent in the results. While the growth of agricultural production appears to require less energy use, it is unlikely that the U.S. agricultural sector has invested capital in energy efficiency or pursued technological improvement to reduce the dependence on energy. It is more likely that the U.S. agricultural sector has reduced energy intensity directly due to the budget and output effects.

\section{Summary and Discussion}

The inspiration for this study comes from the documented reduction in energy intensity in the U.S. agricultural sector. While the U.S. agricultural sector has increased the amount for capital and intermediate factors, energy intensity has dramatically decreased over the last few decades. The reduced energy intensity is attributable to increases in energy prices, advances in energy efficiency or changes in output composition, but the literature has paid little attention to identifying the determinants that contribute to the reduction in energy intensity. Given that energy is an important factor for sustainable agriculture, not only does this study contribute to examining the factor demand system with a focus on 
substitution possibilities between energy and non-energy factors, it also identifies the factors that induce the reduced energy intensity. Moreover, this study contributes to the literature by providing statistical information about regional differences in factor substitution and energy intensity.

The empirical analysis in this study was performed by using the translog cost model, which offered critical values in terms of the price elasticities of factor demand. The estimation results indicated that energy demand was more elastic than the demand for capital and labor, implying that agricultural producers were more flexible to adjust energy demand in response to rapid changes in energy prices rather than to adjust capital or labor demand. Substitution possibilities between energy and non-energy factors existed at the national and regional levels in the 2000s, but the results showed that the U.S. agricultural sector had more incentives to increase energy use in response to rising capital and labor prices rather than to increase capital and labor intensiveness in response to increasing energy prices. Moreover, the decomposition results indicated that the budget and output effects were the major driving forces behind the reduced energy intensity. There were few factor substitutions and technological improvements to reduce energy intensity in the U.S. agricultural sector. Variations existed across regions, but it was likely that the increased energy prices forced the U.S. agricultural sector to reduce energy intensity due to the energy budget constraints, while the output growth required less energy use in agricultural production.

The empirical findings in this study would be in line with previous studies. While the output effects would be attributed to the substantial growth of productivity over the last few decades, the budget effects could be explained by the survey results of Beckman et al. [4]. The significant budget effects in this study would be consistent with their survey results, because they showed that most agricultural producers would keep engines served, reduce trips over a field or decrease the absolute amount of energy in response to higher fuel prices. Moreover, the findings regarding factor substitution and technological improvement would be in accordance with the findings of Wing [6], who showed that the price-induced substitution of variable inputs would generate transitory energy savings, while innovation induced by energy prices would have only a minor impact on the U.S. economy. As a consequence, the budget and output effects were the main driving factors that reduced energy intensity in the U.S. agricultural sector. Innovative activities to reduce energy intensity would be needed for sustainable agricultural production, because they could reduce the risk associated with uncertain energy prices.

\section{Conflicts of Interest}

The author declares no conflict of interest.

\section{References}

1. Wang, S.L.; Ball, E. Agricultural Productivity Growth in the United States: 1948-2011; United States Department of Agriculture: Washington, DC, USA, 2014.

2. Pelletier, N.; Audsley, E.; Brodt, S.; Garnett, T.; Henriksson, P.; Kendall, A.; Kramer, K.; Murphy, D.; Nemecek, T.; Troell, M. Energy Intensity of Agriculture and Food Systems. Ann. Rev. Environ. Resour. 2011, 36, 223-246. 
3. Sands, R.D.; Westcott, P.C.; Price, J.M.; Beckman, J.; Leibtag, E.; Lucier, G.; McBride, W.; McGranahan, D.; Morehart, M.; Roeger, E.; et al. Impacts of Higher Energy Prices on Agriculture and Rural Economies. 2011. Available online: http://www.ers.usda.gov/publications/err-economic-research-report/err123.aspx (accessed on 20 January 2015).

4. Beckman, J.; Borchers, A.; Jones, C. Agriculture's Supply and Demand for Energy and Energy Products. 2013. Available online: http://ssrn.com/abstract=2267323 (accessed on 20 January 2015).

5. Welsch, H.; Ochsen, C. The Determinants of Aggregate Energy Use in West Germany: Factor Substitution, Technological Change and Trade. Energy Econ. 2005, 27, 93-111.

6. Wing, I.S. Explaining the Declining Energy Intensity of the U.S. Economy. Resour. Energy Econ. 2008, 30, 21-49.

7. Canning, P.; Charles, A.; Huang, S.; Polenske, K.R.; Waters, A. Energy Use in the U.S. Food System; United States Department of Agriculture: Washington, DC, USA, 2010.

8. Wang, S.L.; McPhail, L. Impacts of Energy Shocks on U.S. Agricultural Productivity Growth and Commodity Prices-A Structural VAR Analysis. Energy Econ. 2014, 46, 435-444.

9. Wang, Q.; Zhou, P.; Zhao, Z.; Shen, N. Energy Efficiency and Energy Saving Potential in China: A Directional Meta-Frontier DEA Approach. Sustainability 2014, 6, 5476-5492.

10. Ball, V.E.; Färe, R.; Grosskopf, S.; Margaritisd, D. The Role of Energy Productivity in U.S. Agriculture. Energy Econ. 2015, 49, 460-471.

11. Apostolakis, B.E. Energy-Capital Substitutability/Complementarity: The Dichotomy. Energy Econ. 1990, 12, 48-58.

12. Thompson, P.; Taylor, T.G. The Capital-Energy Substitutability Debate: A New Look. Rev. Econ. Stat. 1995, 77, 565-569.

13. Berndt, E.R.; Wood, D.O. Technology, Prices, and Derived Demand for Energy. Rev. Econ. Stat. 1975, 57, 259-268.

14. Griffin, J.M.; Gregory, P.R. An Intercountry Translog Model of Energy Substitution Responses. Am. Econ. Rev. 1976, 66, 845-857.

15. Özatalay, S.; Grubaugh, S.; Long, T.V. Energy Substitution and National Energy Policy. Am. Econ. Rev. 1979, 69, 369-371.

16. Berndt, E.R.; Wood, D.O. Engineering Econometric Interpretation of Energy-Capital Complementary. Am. Econ. Rev. 1979, 69, 342-354.

17. Pindyck, R. Interfuel Substitution and the Industrial Demand for Energy: An International Comparison. Rev. Econ. Stat. 1979, 61, 169-179.

18. Ray, S.C. A Translog Cost Function Analysis of U.S. Agriculture, 1939-77. Ame. J. Agric. Econ. 1982, 64, 490-498.

19. Frondel, M.; Schimdt, C.M. The Capital-Energy: An Artifact of Cost Shares? Energy J. 2002, 23, 53-79.

20. Roy, J.; Sanstad, A.H.; Sathaye, J.A.; Khaddaria, R. Substitution and Price Elasticity Estimates using Inter-Country Pooled Data in a Translog Cost Model. Energy Econ. 2006, 28, 706-719. 
21. Koetse, M.J.; de Groot, H.L.; Florax, R.J. Capital-Energy Substitution and Shift in Factor Demand: A Meta-Analysis. Energy Econ. 2008, 30, 2236-2251.

22. Kim, J.; Heo, E. Asymmetric Substitutability between Energy and Capital: Evidence from the Manufacturing Sectors in 10 OECD Countries. Energy Econ. 2013, 40, 81-89.

23. Tovar, M.A.; Iglesias, E.M. Capital-Energy Relationships: An Analysis when Disaggregating by Industry and Different Types of Capital. Energy J. 2013, 34, 129-150.

24. Fuss, M. The Demand for Energy in Canadian Manufacturing: An Example of the Estimation of Production Function with Many Inputs. J. Econ. 1977, 5, 89-116.

25. Christensen, L.R.; Jorgenson, D.W.; Lau, L.J. Transcendental Logarithmic Production Frontiers. Rev. Econ. Stat. 1973, 55, 28-45.

26. Kratena, K. Technical Change, Investment and Energy Intensity. Econ. Syst. Res. 2007, 19, 295-314.

27. Ma, H.; Oxley, L.; Gibson, J.; Kim, B. China’s Energy Economy: Technical Change, Factor Demand and Interfactor/Interfuel Substitution. Energy Econ. 2008, 30, 2167-2183.

28. Ma, H.; Oxley, L.; Gibson, J. Substitution Possibilities and Determinants of Energy Intensity for China. Energy Policy 2009, 37, 1793-1804.

29. Ma, H.; Oxley, L.; Gibson, J.; Kim, B. Modeling China's Energy Consumption Behavior and Changes in Energy Intensity. Environ. Model. Softw. 2009, 24, 1293-1301.

30. Zha, D.; Zhou, D.; Ding, N. The Determinants of Aggregated Electricity Intensity in China. Appl. Energy 2012, 97, 150-156.

31. USDA Economic Research Service (USDA-ERS). Agricultural Productivity in the U.S. 2015. Available online: http://www.ers.usda.gov/ data-products/agricultural-productivity-in-the-us.aspx (accessed on 20 January 2015).

32. Barton, G.T. Changing Geographic Location of Agricultural Production. Increasing Understanding of Public Problems and Policies; United States Department of Agriculture: Washington, DC, USA, 1961.

33. Pindyck, R.S.; Rotemberg, J.J. Dynamic Factor Demands and the Effects of Energy Price Shocks. Am. Econ. Rev. 1983, 73, 1066-1079.

34. Debertin, D.L.; Pagoulatos, A.; Aoun, A. Impacts of Technological Change on Factor Substitution between Energy and Other Inputs within U.S. Agriculture, 1950-79. Energy Econ. 1990, 12, 2-10.

(c) 2015 by the author; licensee MDPI, Basel, Switzerland. This article is an open access article distributed under the terms and conditions of the Creative Commons Attribution license (http://creativecommons.org/licenses/by/4.0/). 